\title{
THE ROLE OF KETOACID ANALOGS WITH DIETARY PROTEIN RESTRICTION IN CHRONIC KIDNEY DISEASE PATIENTS
}

\author{
Ammar Ammar \\ aDepartement of Internal Medicine, Faculty of Medicine, Univsersitas Airlangga- Dr Soetomo Hospital, Surabaya
}

\begin{abstract}
Introduction Chronic Kidney Disease (CKD) is abnormalities of kidney structure or function occurring for more than 3 months with implications for healths. The use of many interventions to delay the need for dialysis treatment in patients with $\mathrm{CKD}$ in the last stage, until recently, is a primary challenge. We need to remember that high protein intake leads to an increase in glomerular pressure and hyperfiltration that negatively influence on the kidneys.
\end{abstract}

Objective This review article was created to provide knowledge to medical personnel about the importance of nutritional intervention with protein restriction in chronic kidney disease patients. In order to improve the quality of life related to delay the need for hemodialysis.

Methods The Method of making this review article by summarizing from various scientific journal articles, most of which have been published in the last 10 years through BMC Nephrology, NEJM, IJBCP, BMJ Global Health, and J Am Soc Nephrology.

Result One of the existing interventions, nowadays, is using the very low-protein diet intervention $(0.3-0.4 \mathrm{~g}$ protein/kgBW/day). However, the impact of this dietary protein restriction can increase the risk of malnutrition and cachexia. The many research currently available show that safe protein requirement is needed for the body, such as giving ketoacid analogs. Ketoacid analogs can be used as a substitute for each amino acid without providing nitrogen products.

Conclusion The very low-protein diet with ketoacid analogs has many benefits, for example, providing sufficient and optimal energy and nutrition to prevent malnutrition. Besides, the other benefits are the ability to reduce the uremic toxins, reduce proteinuria, increase the calcium and phosphate metabolism, repair the insulin sensitivity, improve the lipid profile, inhibiting the progress of CKD, and prevent cachexia.

Keywords: ketoacid analogs, dietary protein restriction, chronic kidney disease

\section{Introduction}

Chronic Kidney Disease is abnormalities of kidney structure or function occurring for more than 3 months with implications for healths according to the definition from the KDIGO (Kidney Disease Improving Global Outcomes) in 2012 [1]. The factors causing chronic kidney disease (CKD) are varied. To date, chronic kidney disease is still a global health problem with a rising incidence rate annually and costs a high amount of money in the health system [2].

A study published by the GBD (Global Burden of Disease) in 2015 recorded around 1.2 million people were dead due to chronic kidney disease and the mortality rate increased rapidly by $31.7 \%$ in the last decade [3]. A study of meta-analysis estimated that the global prevalence of CKD in a general population around the world was around 11-13\%, and the majority of the cases were those with stage 3 [4]. Early detection and good management planning can inhibit the progress of chronic kidney disease and can improve the life of patients with CKD [1]. 
Chronic kidney disease in the last stage is a condition closely associated with high mortality, poor quality of life, and requires high costs. The use of many interventions to postpone the need for dialysis treatment in patients with $\mathrm{CKD}$ in the last stage, until recently, is a primary challenge. One of the existing interventions, nowadays, is using the low-protein diet intervention [5]. High protein intake leads to an increase in glomerular pressure and hyperfiltration that negatively influence on the kidneys. CKD is characterized by an accumulation of some dissolved organic substances known as uremic toxins. Most of the uremic toxins are produced by degrading amino acids done by intestinal microbiota and can accelerate the progress of CKD. Therefore, reducing the protein intake is expected to be able to maintain kidney function and reduce uremic toxicity. However, the impact of this dietary protein restriction can increase the risk of malnutrition and cachexia. Safe protein intake is, therefore, needed for the body, such as giving ketoacid analogs. Ketoacid analogs are the precursor of amino acids performing the transamination in the chemical reaction to transfer the amine groups to keto acid for structuring new amino acids. This path is responsible for the deamination of most amino acids. Through this conversion, ketoacid analogs can be used as a substitute for each amino acid without providing nitrogen products [6].

The diet intervention was practiced in the last few decades using the existing protein regimens, such as a low-protein diet $(0.6 \mathrm{~g}$ protein $/ \mathrm{kgBW} /$ day $)$ and a very low-protein $\operatorname{diet}(0.3-0.4 \mathrm{~g}$ protein $/ \mathrm{kgBW} / \mathrm{day})$ as well as the nitrogen-free ketoacid analogs. The very low-protein diet with ketoacid analogs has many benefits, for example, providing sufficient and optimal energy and nutrition to prevent malnutrition. Besides, the other benefits are the ability to reduce the uremic toxins, reduce proteinuria, increase the calcium and phosphate metabolism, repair the insulin sensitivity, improve the lipid profile, and prevent malnutrition and cachexia [7].

The dietary protein restriction with ketoacid analog supplementation can be considered as one of the primary approaches for a chronic kidney disease management program. Hence, the compilation of this paper is considered important to understand more benefits obtained by the approach of dietary protein restriction of 0.3 $0.4 \mathrm{~g} / \mathrm{kgBW} /$ day using ketoacid analogs, thus the patients with chronic kidney disease can have better life quality due to the needs for dialysis that can be delayed, the ability to prevent malnutrition, and the ability to inhibit the progress of the chronic kidney disease [5,7]

\section{Diet Intervention in Patients with Chronic Kidney Disease}

Diet intervention is one of the main components of the management of patients with chronic kidney disease aiming at minimizing the uremic symptoms, inhibiting the progress, and providing optimal nutritional 
status. For restricting the accumulation of nitrogenous waste products and slowing down the development of chronic kidney disease, dietary protein restriction has been recommended for patients with moderate to serious chronic kidney disease [8]. High protein intake causes an increase in glomerular pressure and hyperfiltration that can give a negative impact on the kidneys. CKD is characterized by the accumulation of some dissolved organic substances known as uremic toxins. Most of the uremic toxins are produced by degrading amino acids done by intestinal microbiota and can accelerate the progress of CKD. The diet intervention was practiced in the last few decades using the existing protein regimens, such as the conventional low-protein diet $(0.6 \mathrm{~g}$ protein $/ \mathrm{kgBW} / \mathrm{day})$ and very low-protein diet (0.3-0.4 g protein/kgBW/day) as well as the nitrogen-free ketoacid analogs. The protein diet with 0.3-0.4 $\mathrm{g} / \mathrm{kgBW} /$ day with the ketoacid analog supplementation has many benefits, such as providing sufficient and optimal energy and nutrition to prevent malnutrition. Besides, the other benefits are the ability to reduce the uremic toxins, reduce proteinuria, increase the calcium and phosphate metabolism, repair the insulin sensitivity, improve the lipid profile, prevent malnutrition and cachexia, slow down the progress of the disease, and improve the life quality $[7,9]$.

\section{Pharmacology of Ketoacid Analogs}

Ketoacid analogs are a precursor of essential amino acids consisting of simple carbon groups performing the transamination in the chemical reaction to transfer the amine groups to a ketoacid to structure new amino acids. This path is responsible for the deamination of most amino acids. Through this conversion, ketoacid can be used as a substitute for each amino acid without providing nitrogen products. If this diet does not provide sufficient essential amino acids and calories, the nitrogen balance can be negative and induce cachexia. Therefore, providing this ketoacid analog is beneficial for increasing the protein status by restricting the nitrogen load in the body. The parameter that can be measured regarding the act of giving amino acids is by evaluating the urea level in the urine. If the urea level in the urine is high, the excessive protein catabolism in the body will happen as a result of a high protein diet [6].

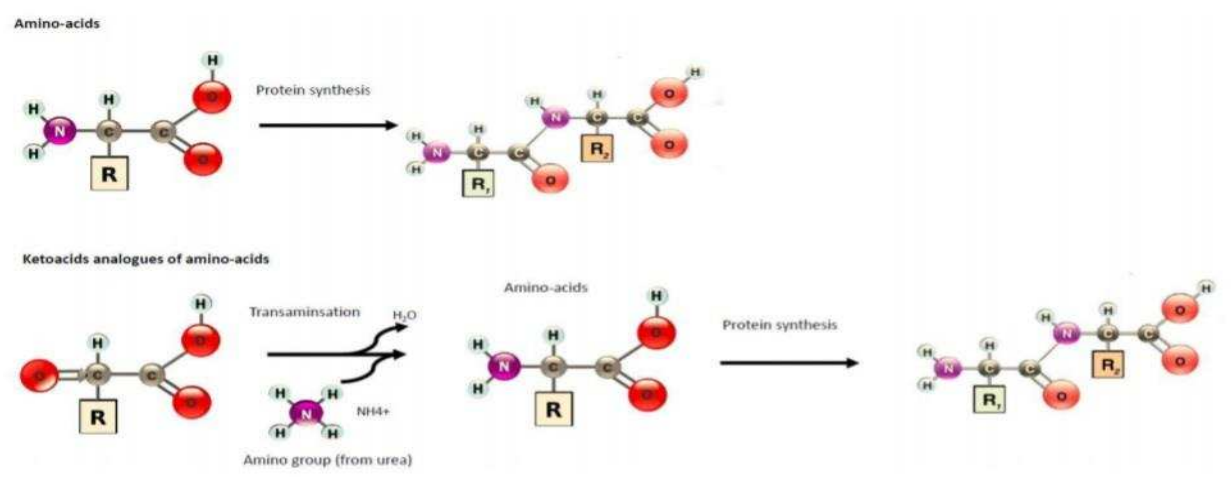

Figure 1. The Mechanism of Transamination of Ketacid Analogs and Amino Acids in the Protein Synthesis [6]. 
The pharmacodynamic properties of ketoacid analogs in the absorption process, keto analogs, and hydroxy analog are transaminated into essential amino acids by taking nitrogen, so it can minimize the formation of urea by reusing the amine groups. Therefore, the accumulation of uremic toxins is declining. The ketoacid analogs do not cause hyperfiltration in the nephron. Besides, it can repair the condition of renal osteodystrophy, hyperphosphatemia, and secondary hyperparathyroidism. The pharmacokinetic properties of ketoacid analogs in amino acids and their integration in the metabolic pathways cannot be denied that they are excellent. In patients with uremia, the levels in the plasma will change, but its absorption is not disturbed. The changed levels of plasma are supposed to happen to occur due to the post-absorption kinetic disturbance. In healthy people, the ketoacid level in the plasma increases in 10 minutes after being given orally, and the peak level occurs in around 20-60 minutes and after 90 minutes, the level becomes more stable at a basic level range. The absorption in the gastrointestinal is extremely fast and the transamination is rapid. The pathway of physiologically using ketoacid analogs in the body is supplied exogenously and rapidly to the metabolic cycle. Ketoacid analogs follow the same catabolic pathways as that of classic amino acids. To date, there is no specific study on ketoacid excretion [10].

Some specific things need to be noted in the monitoring of giving ketoacid analogs, such as calcium levels that need to be monitored regularly, the level of phosphate serum, and ensuring sufficient calorie intake. Contraindications happen in patients suffering from hypersensitivity towards active substances or one of them, patients suffering from hypercalcemia and disorders of amino acid metabolism. The side effects of giving ketoacid are barely found, and hypercalcemia is one of the effects that rarely occur. If hypercalcemia happens, the vitamin D intake can be minimized, and for persistent hypercalcemia, the ketoacid dose and the intake of other sources need to be minimized [10].

The composition of ketoacid analogs and essential amino acids (mg) in one tablet preparation is as follows [9]:

$\begin{array}{ll}\text { Calcium-Keto-DL-isoleucine } & 67 \mathrm{mg} \\ \text { Calcium-Ketoeucine } & 101 \mathrm{mg} \\ \text { Calcium-Ketophenylalanine } & 68 \mathrm{mg} \\ \text { Calcium-Ketovaline } & 86 \mathrm{mg} \\ \text { Calcium-Hydroxy-DL-methionine } & 59 \mathrm{mg} \\ \text { L-Lysine monoacetate } & 105 \mathrm{mg} \\ \text { L-Threonine } & 53 \mathrm{mg} \\ \text { L-Tryptophan } & 23 \mathrm{mg} \\ \text { L-Histidine } & 38 \mathrm{mg} \\ \text { L-Tyrosine } & 30 \mathrm{mg} \\ \text { Total Nitrogen } & \\ \text { Total-Ca/tablet } & 36 \mathrm{mg} \\ & 50 \mathrm{mg}\end{array}$




\section{Therapy of Ketoacid Analogs using Dietary Protein Restriction}

Dietary protein restriction with ketoacid supplementation can be considered as one of the primary approaches of a chronic kidney disease management program. The favorable effects of dietary protein restriction completed by giving ketoacid analogs are decreasing nitrogen wastes, oxidative stress, and inflammatory responses, including transforming growth factor-beta and giving protection by combating the hemodynamic changes in glomerular hyperfiltration. These ketoacid analogs are usually recommended for predialysis patients with CKD to reduce the metabolism of toxic products and improve the nutritional status [11]. Ketoacid does not only function to replace each amino acid and protect the nitrogen balance, but it also has other following properties [12]:

1. The ketoacid analogs of branched-chain amino acids can stimulate protein synthesis and inhibit protein degradation. Giving leucine orally can increase the phosphorylation of two proteins (eukaryotic initiation factor eIF4E binding protein (4E-BP)1 and ribosomal protein S6 kinase S6K1) regulating the parts of the initiation stage in the translation that involves the mRNA binding to 40S ribosomal subunits.

2. Giving ketoacid analogs can partially improve the amino acid profile in patients with uremia that indirectly and simultaneously improve metabolic acidosis due to the reduced amino acids containing sulfur. Besides, the decrease in the protein excretion in the urine due to dietary protein restriction followed by sufficient ketoacid intake contributes to the increase in serum albumin and the maintenance of nutritional status at a normal range. The ketoacid analogs also have a low stimulation effect on kidney hyperfiltration, so the kidney load becomes lighter. Giving the ketoacid analogs of branched-chain amino acids with dietary protein restriction stimulate the pancreas to stimulate glucagon and the secretion of hepatic glucagon-stimulated cyclic AMP (cAMP) for replacing the lost amino acids.

3. Therapy of ketoacid analogs has an advantageous effect on improving the lipid profile, especially those related to the decrease in the triglyceride level and the increase in the HDL cholesterol level. This is important because the rapid development of the atherosclerosis process is frequently encountered in patients with uremia.

4. The role of dietary protein restriction without the animal protein content is decreasing the phosphor intake and the calcium contained in the ketoacid has an advantageous effect on calcium metabolism, disturbed phosphate, and secondary hyperparathyroidism.

5. The ketoacid analogs can repair the carbohydrate metabolism disorders observed in patients with uremia. The advantageous effects of ketoacid include the ability to increase the insulin sensitivity in tissues, decrease 
insulin resistance, and the ability to increase the level of energy production in patients, especially in a group of obese people who do not depend on insulin in patients with CKD.

Several results from the existing consensus presently about the therapy of ketoacid analogs with dietary protein restriction in patients with chronic kidney disease are as follows [6,9]

- The therapy of giving ketoacid analogs followed by the dietary protein restriction that has been planned well is a part of the safe therapy program that does not cause malnutrition and improve metabolic abnormalities related to renal insufficiency. Also, it can slow down the progress of CKD and delay the time until dialysis is needed to cure the uremic symptoms.

- The holistic and team approach between patients-physicians-nutritionists is strongly required to result in optimal results.

- Giving ketoacid analogs followed by dietary protein restriction is a cost-effective therapy and can improve the patients' life quality in the pre-dialysis stages

- The special guide and recommendations from many pieces of literature about the therapy of ketoacid analogs followed by dietary protein restriction are described as follow [9]:

$\checkmark$ The daily protein intake with a low-protein diet followed by ketoacid analog supplementation may not be over $0.6 \mathrm{~g} / \mathrm{kgBW} / \mathrm{day}$. The recommended optimal protein intake is around Asupan 0.3-0.4 g/kgBW/day

$\checkmark$ The recommended dose of ketoacid is $0.1 \mathrm{~g} / \mathrm{kgBW} /$ day or 1 tablet $/ 5-8 \mathrm{kgBW} /$ day

$\checkmark$ The recommended daily energy intake is $35 \mathrm{kcal} / \mathrm{kgBW} /$ day

$\checkmark$ The low-protein diet of $0.6 \mathrm{~g} / \mathrm{kgBW} / \mathrm{day}$ is indicated for patients with creatinine clearance of around 50 $\mathrm{ml} / \mathrm{min} / 1.73 \mathrm{~m}^{2}$; the therapy of ketoacid analogs with protein restriction of $0.3-0.4 \mathrm{~g} / \mathrm{kgBW} /$ day is indicated for patients with creatinine clearance of around $20-25 \mathrm{ml} / \mathrm{min} / 1.73 \mathrm{~m}^{2}$ (however, the recommendation guide is different in every country about adjusting ketoacid dose). In patients undergoing dialysis treatment, the required protein intake is $1.2 \mathrm{~g} / \mathrm{kgBW} /$ day

$\checkmark$ In the first three months after giving the therapy of ketoacid analogs with dietary protein restriction of 0.3$0.4 \mathrm{~g} / \mathrm{kgBW} / \mathrm{day}$, the recommendation is evaluating several parameters, such as body weight, the level of urea in a 24-hour urine sample, the level of urea nitrogen in the blood, creatinine serum, the level of creatinine clearance, electrolyte, calcium, phosphate, parathyroid hormone (PTH), blood gas analysis, complete blood count (CBC), including hemoglobin, lipid profile, blood glucose level, albumin serum and the level of transferrins 
The result of protein metabolism from foods accumulated into waste products is from essential and nonessential amino acids from the protein degradation in food, then, it results in the increase in urea production as the waste products that shall be eliminated from the kidney. The main objective in utilizing the protein restriction in food is to minimize the waste products that are not excreted and maintain a sufficient nutritional status. The success of the dietary protein restriction therapy strongly requires a periodic evaluation of the patient's compliance and nutritional status. There is a simple method that can estimate the protein intake in patients with CKD. This method is based on the urea nitrogen products because nitrogen is from the protein catabolism or endogenous protein, so the amount of excreted urea nitrogen added to accumulated urea nitrogen in a parallel manner is equal to eventual protein intake [13].

The evaluation of nutritional status in patients with CKD cannot only be done using one parameter, yet it needs to cover several parameters, such as patients' clinical conditions, medical record, physical examination, history of dietary pattern, biochemical examination (albumin, transferrins, potassium, calcium, phosphate, glucose, and cholesterol), anthropometric assessment, and subjective global assessment [14]

Around 30-50\% of patients with CKD undergoing dialysis treatment are estimated to suffer from proteinenergy malnutrition. Nutritional status is an important predictor of patients' clinical condition undergoing chronic dialysis treatment since uremic malnutrition is strongly correlated with an increased risk of mortality and morbidity. The frequently occurring disorders in nutritional characterization include the reduction in protein or albumin serum, lower body mass assessed by the anthropometric measurement, global subjective assessment, and the reduction in nutrient intake. The reduced muscle mass is the most significant predictor of morbidity and mortality in patients undergoing dialysis treatment. Oral supplementation of ketoacid in patients with CKD undergoing dialysis treatment has some advantageous effects, such as the compensation of lost essential amino acids during dialysis, normalization of the low amino acid level in the plasma, especially branched-chain amino acids, overall improvement of nutritional status (albumin, global subjective assessment, and bodyweight) in malnourished patients undergoing dialysis treatment, and normalization of calcium and phosphate disorders (the increase in calcium serum the decrease in phosphate) [15].

The special recommendations of nutrition in patients with chronic kidney disease (CKD) undergoing dialysis treatment are as follows [9]:

$\checkmark \quad$ Protein intake of $1.2 \mathrm{~g} / \mathrm{kgBW} /$ day

$\checkmark$ Energy intake of $35 \mathrm{kcal} / \mathrm{kgBW} /$ day for those aged $\leq 60$ years old and $30-35 \mathrm{kcal} / \mathrm{kgBW} /$ day for those aged $\geq 60$ years old 


\section{$\checkmark$ The recommended ketoacid dose of 1 tablet $/ 5-8 \mathrm{kgBW} /$ day}

A study conducted by Feiten et al. reported that dietary protein restriction of $0.3 \mathrm{~g} / \mathrm{kgBW} /$ day followed by giving ketoacid supplementation can maintain the nutritional status of patients with CKD, improve the calcium and phosphate metabolism, and reduce the urea nitrogen in serum. Several parameters such as urea nitrogen in serum significantly decreases in patients with dietary protein restriction of $0.3 \mathrm{~g} / \mathrm{kgBW} /$ day followed by giving ketoacid for 4 months, from $61.4 \pm 12.8 \mathrm{mg} / \mathrm{dl}$ to $43.6 \pm 14.9 \mathrm{mg} / \mathrm{dl}$, calcium from $1.21 \pm 0.15 \mathrm{mmol} / \mathrm{l}$ to $1.22 \pm$ $0.17 \mathrm{mmol} / \mathrm{l}$, and serum phosphate from $4.6 \pm 0.5 \mathrm{mg} / \mathrm{dl}$ to $4.0 \pm 1.1 \mathrm{mg} / \mathrm{dl}$. Meanwhile, in patients treated with dietary protein restriction of $0.6 \mathrm{~g} / \mathrm{kgBW} / \mathrm{day}$, there is no significant reduction in the urea nitrogen in serum from $61.7 \pm 23.8 \mathrm{mg} / \mathrm{dl}$ to $56.8 \pm 18.2 \mathrm{mg} / \mathrm{dl}$; calcium decreases from $1.31 \pm 0.05 \mathrm{mmol} / \mathrm{l}$ to $1.26 \pm 0.07 \mathrm{mmol} / \mathrm{l}$, while serum phosphate tends to be constant from $4.6 \pm 0.9 \mathrm{mg} / \mathrm{dl}$ to $4.6 \pm 1.4 \mathrm{mg} / \mathrm{dl}$. For the parameter of serum creatinine, there is no significant difference in these two groups after a 4-month therapy. Whereas, for body mass index, body fat, triceps skinfold thickness, and mid-arm muscle circumference, there is no significant difference in these two groups after 4 months of conducting the study [8].

A prospective study of the Institute of Clinical Medicine and Department of experimental nephrology in Praha evaluated 2 groups for 12 months, namely the first group treated with ketoacid followed by a low-protein diet of $0.6 \mathrm{~g} / \mathrm{kgBW} /$ day and ACE inhibitors, and the second group without ketoacid treatment. This study obtained a significant reduction in proteinuria from the first group, improved lipid metabolism, and improved inflammatory parameters, such as free radicals, CRP, TGF- $\beta$, and P-selectin $(\mathrm{p}<0.01)$. Also, the parameter of creatinine clearance in the first group by giving ketoacid showed a constant trend from $23.48 \mathrm{ml} / \mathrm{min} / 1.73 \mathrm{~m}^{2}$ to 22.82 $\mathrm{ml} / \mathrm{min} / 1.73 \mathrm{~m}^{2}$, the creatinine clearance in the second group without giving ketoacid tended to decrease from $22.84 \mathrm{ml} / \mathrm{min} / 1.73 \mathrm{~m}^{2}$ to $21.34 \mathrm{ml} / \mathrm{min} / 1.73 \mathrm{~m}^{2}$ ( $\left.\mathrm{p}<0.01\right)$. Meanwhile, the parameter of albumin, transferrins, and branched-chain amino acids significantly increased in the group treated with ketoacid for 3 years $(p<0.01)[12]$. A cohort study conducted in Hungary for evaluating the goodness of fit and the effect of dietary protein restriction by giving ketoacid analogs in the progress of CKD obtained a result that patients treated with ketoacid intervention needed dialysis treatment after a period of $40 \%$ longer than those without diet intervention. From the economic aspect, the annual cost for patients with ketoacid analog diet intervention was around 1/10 from the dialysis cost and could improve the patients' life quality. An experimental study conducted in Mexico in patients with CKD treated with dietary protein restriction $(0.4 \mathrm{~g} / \mathrm{kgBW} /$ day $)$ followed by giving 1 tablet ketoacid $/ 8 \mathrm{kgBW} / \mathrm{day}$ compared to the dietary protein restriction of $0.6 \mathrm{~g} / \mathrm{kgBW} /$ day showed that keto diet regimens could repair the metabolic disorders and reduce the lipid serum, uric acids, glucose, and phosphate. Also, it could increase calcium 
and hemoglobin. Subsequently, the keto diet regimens can maintain the kidney function to not degrade with a constant clearance in 42 months, while in patients with only dietary protein restriction $(0 ., 6 \mathrm{~g} / \mathrm{kgBW} / \mathrm{day})$ with the same duration, the average creatinine clearance decreased to $10 \mathrm{ml} / \mathrm{min} / 1.73 \mathrm{~m}^{2}$ [16].

A prospective study in 2014 by Khan et al. was conducted in patients with CKD stage 3-4 by comparing group 1 receiving the conservative management treatment and placebo against group 2 receiving the conservative management treatment and ketoacid analog tablet three times a day for 12 weeks. The study obtained several results, such as the reduction in creatinine $(\mathrm{p}<0.05)$, the reduction in the blood urea nitrogen $(\mathrm{p}<0.001)$, the reduction in serum potassium $(\mathrm{p}<0.001)$, improved lipid profile $(\mathrm{p}<0.05)$, increased serum calcium $(\mathrm{p}<0.01)$, increased glomerular filtration rate $(\mathrm{p}<0.001)$, and increased total urine volume in group 2 receiving the conservative management treatment and ketoacid treatment [16]. Another study by Garneata et al., comparing the patients with CKD with a glomerular filtration rate (GFR) $<30 \mathrm{ml} / \mathrm{min} / 1.73 \mathrm{~m}^{2}$ for 3 months between those treated with keto diet regimens (protein $0.3 \mathrm{~g} / \mathrm{kgBW} /$ day and $1 \mathrm{tablet} / 5 \mathrm{kgBW} /$ day ketoacid) and those treated with only a low-protein diet of $0.6 \mathrm{~g} / \mathrm{kgBW} /$ day, concluded that several metabolic parameters in patients receiving this keto diet regimen showed improvement in serum phosphate and nitrogen urea $(\mathrm{p}<0.001)$. Meanwhile, the GFR in patients receiving keto diet regimens was quite constant; the average rate was from $18.0 \mathrm{ml} / \mathrm{min} / 1.73 \mathrm{~m}^{2}$ to 17.4 $\mathrm{ml} / \mathrm{min} / 1.73 \mathrm{~m}^{2}[7]$.

A retrospective cohort study by Satirapoj et al. in 140 patients with CKD stage 3-4 by comparing group 1 with a low-protein diet of $0.6 \mathrm{~g} / \mathrm{kgBW} / \mathrm{day}$ and group 2 with a low-protein diet of $0.3 \mathrm{~g} / \mathrm{kgBW} / \mathrm{day}$ and ketoacid analog supplementation of $100 \mathrm{mg} / \mathrm{kgBW} /$ day for $12 \mathrm{months}$. The study obtained that the increase in urea nitrogen from $22.8 \pm 7.3$ to $24.3 \pm 7.1 \mathrm{mg} / \mathrm{dl}$, the increase in serum creatinine from $1.6 \pm 0.4$ to $1.8 \pm 0.4 \mathrm{mg} / \mathrm{dl}$, and the decrease in the glomerular filtration rate (GFR) from $41.60 \pm 10.2$ to $36.8 \pm 8.8 \mathrm{ml} / \mathrm{min} / 1.73 \mathrm{~m}^{2}$ occurred in group 1. Meanwhile, the reduction in the blood urea nitrogen from $22.2 \pm 6.76$ to $21.9 \pm 7.0 \mathrm{mg} / \mathrm{dl}$, an insignificant change in serum creatinine from $1.7 \pm 0.3$ to $1.7 \pm 0.5 \mathrm{mg} / \mathrm{dl}$, and an insignificant change in the glomerular filtration rate (GFR) from $39.1 \pm 9.2$ to $38.9 \pm 12.0 \mathrm{ml} / \mathrm{min} / 1.73 \mathrm{~m}^{2}(\mathrm{p}<0.001)$ happened in the group 2 . The other parameters, such as proteinuria, albumin, hemoglobin, serum potassium, serum bicarbonate, serum calcium, and serum phosphate, showed a relatively constant result. After conducting the Cox regression analysis, the result showed that the treatment using the dietary protein restriction of $0.3 \mathrm{~g} / \mathrm{kgBW} /$ day by giving ketoacid significantly protected the kidney from the decrease in the glomerular filtration rate (GFR) of $>10 \%$ per year (Adjusted HR 0.42; CI 95\%, 0.23-0.79; $\mathrm{P}=0.006)$. Therefore, applying the dietary protein restriction of $0.3 \mathrm{~g} / \mathrm{kgBW} / \mathrm{day}$ and giving ketoacid analogs may be proven as an effective alternative for conservative management in patients with 
$\mathrm{CKD}$, so the progress of the disease can be prevented and maintain the nutritional status of patients with CKD to prevent them from suffering from malnutrition $[11,18]$.

\section{Summary}

Diet intervention is one of the primary components of the management in patients with chronic kidney disease these days aiming at minimizing the uremic symptoms, inhibiting the progress, and giving optimal nutritional status. Several results of the existing clinical studies these days can conclude that there are some advantageous effects of the dietary protein restriction of $0.3 \mathrm{~g} / \mathrm{kgBW} /$ day followed by ketoacid analog supplementation, such as improving the metabolic parameters, maintaining the optimal nutritional status in patients with CKD to prevent them from suffering from malnutrition and cachexia, and inhibiting the progress of CKD. The usage recommendation of ketoacid these days does not reach a consensus yet. However, several international research centers, presently, recommend implementing ketoacid analog supplementation in the management of patients with chronic kidney disease.

\section{REFERENCES}

1. Canney M, Birks P, Levin A. Epidemiology of Chronic Kidney Disease-Scope of the Problem. InChronic Renal Disease 2020 Jan 1 (pp. 75-89). Academic Press.

2. Hill NR, Fatoba ST, Hirst JA, Callaghan CA, Lasserson DS, and Hobs FD, 2016. Global prevalence of chronic kidney disease - a systematic review and meta-analysis. PLoS ONE 2016 11(7): e0158765. doi: 10.1371/journal.pone.0158765

3. Neuen BL, Chadban SJ, Demaio AR, Johnson DW, and Perkovic V. Chronic kidney disease and the global NCDs agenda. BMJ Global Health .2017 2: e000380. doi: 10.1136/bmjgh-2017-000380

4. Luyckx VA, Tonelli M, Stanifer JW. The global burden of kidney disease and the sustainable development goals. Bulletin of the World Health Organization. 2018 Jun 1;96(6):414.

5. Chen TK, Knicely DH, Grams ME. Chronic kidney disease diagnosis and management: a review. Jama. 2019 Oct 1;322(13):1294.

6. Koppe L, Cassani de Oliveira M, Fouque D. Ketoacid analogues supplementation in chronic kidney disease and future perspectives. Nutrients. 2019 Sep;11(9):2071.

7. Garneata L, Stancu A, Dragomir D, Stefan G, Mircescu G. Ketoanalogue-supplemented vegetarian very low-protein diet and CKD progression. Journal of the American Society of Nephrology. 2016 Jul 1;27(7):2164-76.

8. Feiten SF, Draibe SA, Watanabe R, Duenhas MR, Baxmann AC, Nerbass FB, Cuppari L. Shortterm effects of a very-low-protein diet supplemented with ketoacids in nondialyzed chronic kidney disease patients. European journal of clinical nutrition. 2005 Jan;59(1):129-36.

9. Aparicio M, Cano NJ, Cupisti A, Ecder T, Fouque D, Garneata L, Liou HH, Lin S, SchoberHalstenberg HJ, Teplan V, Zakar G. Keto-acid therapy in predialysis chronic kidney disease patients: consensus statements. Journal of Renal Nutrition. 2009 Sep 1;19(5):S33-5.

10. Ikizler TA. Safety of low-protein diets and ketoanalogue supplementation in CKD. Kidney international reports. 2018 May 1;3(3):510-2.

11. Satirapoj B, Vongwattana $P$, Supasyndh $O$. Very low protein diet plus ketoacid analogs of essential amino acids supplement to retard chronic kidney disease progression. Kidney research and clinical practice. 2018 Dec;37(4):384.

12. Kopple JD, Burrowes JD. History of Dietary Protein Treatment for Non-dialyzed Chronic Kidney Disease Patients. Nutrition in Kidney Disease. 2020:19-38. 
13. Mitch WE, Walser M, Steinman TI, Hill S, Zeger S, Tungsanga K. The effect of a keto acidamino acid supplement to a restricted diet on the progression of chronic renal failure. New England Journal of Medicine. 1984 Sep 6;311(10):623-9.

14. Goldstein FD and LaPierre Am. Nutrition and kidney disease. In: Gilbert GJ, Weiner ME. Editors. National kidney foundation's primer on kidney disease. Philadephia; Elsevier Saunderz. 2014 pp 467474

15. Zakar G. Clinical studies on keto/amino acid supplementation of dialysis patients. Am J Kidney Dis. 2005;25(1):27-8.

16. Fouque D, Chen J, Chen W, Garneata L, Hwang SJ, Kalantar-Zadeh K, Kopple JD, Mitch WE, Piccoli G, Teplan V, Chauveau P. Adherence to ketoacids/essential amino acids-supplemented low protein diets and new indications for patients with chronic kidney disease. BMC nephrology. 2016 Dec;17(1):1-5.

17. Khan IA, Nasiruddin M, Haque SF, Khan RA. Clinical evaluation of efficacy and safety of $\alpha$-keto analogs of essential amino acids supplementation in patients of chronic kidney disease. Int $\mathrm{J}$ Basic Clin Pharmacol. 2014 May;3(3):484-9.

18. Zou R, Zhang D, Lv L, Shi W, Song Z, Yi B, Lai B, Chen Q, Yang S, Hua P. Bioinformatic gene analysis for potential biomarkers and therapeutic targets of atrial fibrillation-related stroke. Journal of translational medicine. 2019 Dec;17(1):1-2. 